\title{
Utopias desenvolvimentistas e política social no Brasil
}

\section{Developmentalist utopies and social policy in Brazil}

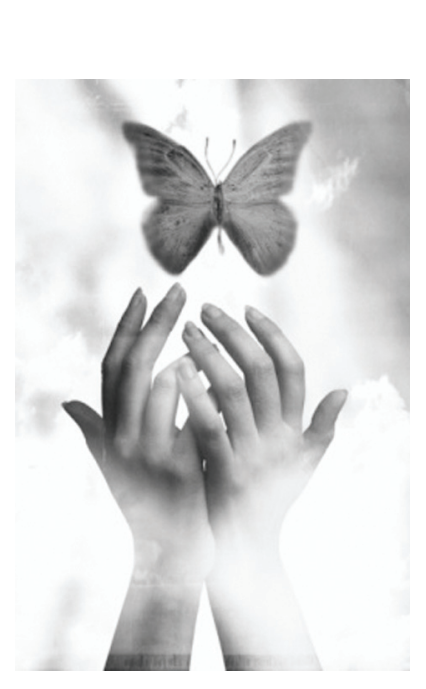

Potyara Amazoneida P. Pereira*

Resumo: Este artigo discute a política social brasileira no marco das aspirações governamentais de transformar o Brasil, desde os anos 1930, em potência emergente, por meio de um processo de desenvolvimento gerido pelo Estado. Só que essas transformações se realizaram de forma dependente do capital internacional e combinaram rupturas e continuidades. Para isso, muito contribuíram os períodos de ditadura e o recente domínio neoliberal, que aprofundaram as desigualdades sociais e impediram a política social de concretizar direitos sociais conquistados formalmente.

Palavras-chave: Desenvolvimentismo brasileiro. Política social. Neoliberalismo. Desigualdade social. Desmonte de direitos.

\begin{abstract}
In this article we discuss the Brazilian social policy guided by the government's aspirations to transform Brazil (since the 1930's) into an emergent potency through a development process managed by the State. However, these transformations depended on the international capital, and they combined ruptures and continuities. The periods of dictatorship and the recent neoliberal dominance contributed to that situation, which deepened social inequalities and prevented the social policy from making social rights that were formally conquered actual.

Keywords: Brazilian developmentalism. Social policy. Neoliberalism. Social inequality. Dismantling of rights.

* Professora titular da Universidade de Brasília (UnB), Brasil, líder do Grupo de Estudos Politiza do PPGPS/SER/IH/UnB e pesquisadora do Neppos/Ceam/UnB e do CNPq.E-mail: potyamaz@gmail.com.
\end{abstract}




\section{Introdução}

efletir sobre a política social da atual fase do capitalismo brasileiro,
caracterizada como "neodesenvolvimentista" e responsável pela
inserção do país no circuito das "potências emergentes" — as fa-
mosas Brics ${ }^{1}$-, implica considerar as tendências mundiais dessa política que, como nunca, encontra-se pressionada por poderosos interesses de classes.Vale dizer, que tal política encontra-se sob o fogo cruzado de interesses que, no âmbito da "totalidade hierarquizada constituída pela economia mundial" (Chesnais, 2010, p. x) dos tempos presentes, reproduzem mais intensamente a disputa desigual entre capital e trabalho por ganhos particulares.

Está certo que a política social brasileira tem peculiaridades que devem ser consideradas. Não obstante isso, vale lembrar que essas peculiaridades não se dão no vácuo. No Brasil, as definições e os rumos da política social não estão imunes a influências internacionalmente hegemônicas, que, embora se processem de forma diferenciada, não estão desconectadas.

Com isso, quero salientar que as mudanças atualmente verificadas nos fundamentos e na prática da política social brasileira não ocorrem de forma isolada, unilateral e autônoma. Pelo contrário, elas fazem parte do processo mundial de reestruturação capitalista, iniciado no final dos anos 1970, cuja justificação ideológica encontra guarida no credo neoliberal desde então dominante.

Por se tratar, esse credo, de um ideário abrangente, que ultrapassa fronteiras na sua missão bem-sucedida de privilegiar o mercado como o agente principal do bem-estar dos indivíduos, ele não poderia deixar de exercer influência no Brasil.

No chamado Primeiro Mundo, o triunfo ideológico do neoliberalismo sobre a política social do segundo pós-guerra, que vigorou entre 1945 a 1975, redundou no desmonte dos três pilares social democratas que sustentaram,

1. "Bric" é um acrônimo formado pelas primeiras letras dos quatro países fundadores do bloco das atuais nações ditas emergentes: Brasil, Rússia, Índia, China. Recentemente a sigla ganhou um S (Brics), referente à África do Sul, que mais tarde foi incluída nesse bloco. 
durante os denominados "trinta anos gloriosos", ${ }^{2}$ essa política, a saber: o pleno emprego (se bem que masculino); a universalização de direitos sociais; e o estabelecimento de um piso socioeconômico, acima da miséria, abaixo do qual ninguém deveria viver (Mishra, 1990).

Desde então, sob o signo de uma nova ética capitalista de regulação social, que condena a proteção pública como direito devido pelo Estado, as políticas sociais enredaram-se na engrenagem da competitividade capitalista mundial, que têm como linha-mestra as regras antissociais do mercado.

\section{Características da utopia desenvolvimentista brasileira e os percalços da política social}

No Brasil as mudanças primeiro-mundistas sempre tiveram repercussões, malgrado aqui não se ter vivenciado anos gloriosos do ponto de vista econômico e social. Mas, como diz Sader (2010), a história mostra que, desde 1930, o país sofreu grandes transformações que mudaram de forma marcante a sua fisionomia econômica, política, social e cultural. Só que, contraditoriamente, essas transformações se realizaram combinando rupturas e continuidades e, portanto, preservando ranços conservadores - e, agora, transformistas, ${ }^{3}$ no sentido gramsciano - num contexto afinado com os apelos modernizantes do capital internacionalizado.

2. Termo cunhado pelo francês Jean Fourastié para se referir às trinta décadas compreendidas entre os anos 1945-75 em que o Estado de Bem-estar europeu (Welfare State, nos países de língua inglesa, e Estado Providência, na França) teve o seu melhor desempenho como provedor de benefícios e serviços na perspectiva da cidadania social.

3. Fenômeno político caracterizado "pela cooptação de lideranças políticas e culturais das classes subalternas [visando] excluí-las de todo efetivo protagonismo nos processos de transformação social" (Coutinho, 2010, p. 38). Na concepção gramsciana, o fenômeno também se refere à obtenção de consenso estratégico pelo bloco no poder, mediante a incorporação passiva de personalidades opositoras e/ou de grupos radicais, que se tornam moderados (Idem). Segundo Oliveira (2010), esse mesmo fenômeno passou a ser identificado no Brasil, do governo Lula (2003-10), com a cooptação de centrais sindicais e de movimentos sociais, antes aguerridos, bem como de parcelas consideráveis das classes populares beneficiárias de programas assistenciais. 
Assim, conforme Sader (2010, p. 12), se antes de 1930 o Brasil era um país rural, agrícola, restrito às elites e voltado para exterior, hoje ele é um país urbano, industrializado, voltado para dentro e com características de Estado nacional (ainda que incompleto). Para isso, foi fundamental uma forte ingerência do Estado no processo de industrialização interna, cujo programa revelou-se socialmente avançado, mormente no campo trabalhista e previdenciário. Porém. isso não significou um divórcio com o progressismo positivista, sempre presente na ordem nacional, desde o Império, e com a vocação agrícola do país. Mesmo assim, o Estado brasileiro, apesar de dependente econômica e culturalmente, criou - à mesma época em que vigorou o Welfare State europeu ${ }^{4}$ - serviços públicos básicos, incluindo os sociais, de par com a garantia de uma ordem jurídica que também regulava as relações entre capital e trabalho (Furtado, 1974).

Foi em meio a essa reorganização econômica, social e política que a política social no Brasil se instituiu, nos anos 1930, associada formalmente a direitos sociais reivindicados por trabalhadores organizados, mas ironicamente submetida a práticas populista se nacional-desenvolvimentistas ${ }^{5}$ do governo ditatorial ${ }^{6}$ de Vargas. Digo ironicamente porque, enquanto nos países capitalistas centrais as políticas sociais conquistadas pela classe trabalhadora floresceram sob a égide das chamadas democracias burguesas, no Brasil tais políticas flo-

\footnotetext{
4. A expressão "Welfare State europeu” é aqui utilizada para destacar o fato de que não existe e nunca existiu um padrão unívoco de Estado de Bem-Estar nos países capitalistas centrais. Por isso, é preciso diferenciar o Estado de Bem-estar relutante e residual dos Estados Unidos, de filiação liberal, do Estado de Bem-estar socialdemocrata, que vigorou na Europa, nos "trinta anos gloriosos" - embora tal Estado tenha apresentado notórias diferenciações no Norte, Centro e Sul desse continente. É por isso que Moreno (2000), nos seus estudos sobre o bem-estar social na Europa, prefere falar das "Europas de bem-estar".

5. Considerado como desenvolvimentismo clássico, inaugurado com Vargas e adotado pelos governos subsequentes até a deflagração do golpe militar em 1964, seu principal objetivo era o de perseguir o desenvolvimento pela via da industrialização, mas sem grandes preocupações com a diminuição das desigualdades sociais.

6. Governo instalado, em 3/11/1930, por meio de um movimento armado que depôs do poder o então presidente da República, Washington Luís, e se estendeu por quinze anos ininterruptos. Inicialmente governando por meio de decretos, por ter revogado a Constituição de 1891, Vargas, em 10 de novembro de 1937, impôs à nação uma nova Constituição que deu inicio ao "Estado Novo", explicitamente ditatorial. Esse Estado vigorou até 1945, quando Vargas foi deposto. Porém o ex-presidente retornou em 1950, eleito pelo povo, e governou, sob regime democrático, até 1954, ano em que se suicidou.
} 
resceram e se adensaram nas ditaduras, sob as bênçãos da burguesia. Prova disso, foi que, no governo republicano de Juscelino Kubitscheck (1956-61), considerado até então o mais democrático, a política social teve um papel marginal. Nesse governo, marcado por um ambicioso sonho nacional-desenvolvimentista de trazer para o país, em cinco anos, um progresso equivalente a cinquenta anos de crescimento industrial, a política social só teve vez como peça subsidiária a realização desse progresso. Não à toa, a educação contida no Plano de Metas do governo Kubitscheck visava quase tão somente preparar recursos humanos para empresas estrangeiras que aqui se estabeleceram, sobretudo as do ramo automobilístico (Pereira-Pereira, 1987).

No período da ditadura militar, instituída com o golpe de 1964, a política social foi amplamente utilizada como compensação ao cerceamento dos direitos civis e políticos, praticado pelo Estado, que, graças à existência à época de um ciclo econômico expansivo internacional, deu continuidade à industrialização desenvolvimentista ${ }^{7}$ no país. E isso explica, de acordo com Oliveira (2010), a ocorrência de um avanço capitalista interno "em suas formas mais violentas" (p. 371). Nunca, afirma esse autor, o dístico positivista da bandeira brasileira - Ordem e Progresso - foi "levado tão ao pé da letra": "poderosas empresas estatais se fortaleceram nos setores produtivos, fusões bancárias foram financiadas por impostos pesados, recursos públicos foram usados sem ambiguidades, não para preservar o velho, mas para produzir o novo - como a Aeronáutica e o ITA, criando a Embraer" (p. 372). Esse foi um aspecto que diferenciou as ditaduras militares do Brasil das de outros países da América Latina, pois neles o Estado ditatorial que se implantou nos anos 1970 conviveu com a recessão econômica, dada a coincidência de sua implantação com "o início do longo período recessivo do capitalismo internacional" (Sader, 2008).

Com efeito, em meados dos anos 1970, ao findar o ciclo expansivo da economia internacional, iniciado no segundo pós-guerra, todo o mundo capitalista conheceu uma nova crise, que se revelou estrutural e se prolonga até os dias de hoje, crise esta causada por desequilíbrios entre sobre acumulação e

7. Nesse período, a ideia de desenvolvimento, além de ter rompido com o populismo do nacional-desenvolvimentismo anterior, priorizava o nacionalismo econômico e o gerenciamento logístico e técnico-burocrático do progresso. 
consumo e pela transformação do excedente produzido pela economia real em capital financeiro.

Face a essa crise capitalista, exacerbada em 2008, o Brasil tem respondido com expedientes que the dão sobrevida como país emergente, ou neodesenvolvimentista, ${ }^{8}$ seja reestruturando seu modelo econômico, seja diversificando a sua dependência externa, ao mesmo tempo em que procura retomar a expansão econômica interna (Sader, 2008). Nesse mister, o país, a par de servir, desde os anos 1990, de plataforma emergente de valorização financeira internacional, graças à adoção de políticas de "securitização da dívida externa, de internacionalização do mercado de títulos públicos e abertura dos fluxos internacionais de capital" (Paulani, 2010, p. 133), tem voltado a explorar suas reservas minerais e vegetais; a praticar o agronegócio; a exportar commodities e a reciclar a sua dependência externa, que, agora, deixa de ser tecnológica, "típica da acumulação industrial", para ser financeira, "típica do capitalismo rentista" (Idem, p. 133-34). Ou seja, além de o país voltar a sua antiga condição de produtor e exportador de bens primários, ou a sua vocação agrícola, ele se vê submetido ao que vem sendo denominado "servidão financeira".

Voltando aos anos 1980, cabe mencionar um fato notório no histórico de altos e baixos do híbrido desenvolvimento brasileiro e da sua política social: paralelamente à recessão econômica, que também atingiu o Brasil —, acompanhada de inflação, endividamento do setor público e de baixas taxas de crescimento - o o país assistiu, em 1985, ao fim da ditadura e ao advento de um novo período de redemocratização; e, nesse período, a conquista de maior simbolismo foi a promulgação, em 1988, da Constituição da República (CF/88), conhe-

8. Termo utilizado, não sem polêmica, para denominar os governos brasileiros dos últimos anos, particularmente os dos dois mandatos do ex-presidente Lula, que visaram a integração da esfera nacional com a internacional com o objetivo de promover o crescimento econômico com inclusão social. Apesar de esse tipo de desenvolvimento reatar o fio da meada da versão nacional-popular clássica, apresenta as seguintes principais particularidades: intervenção estatal num contexto de estabilidade institucional e monetária, capacidade econômica, intento de projetar o país como potência emergente no marco do processo de globalização neoliberal, mas com resguardo de uma soberania relativa, e pretensão de liderança regional.

9. Servidão aos princípios e práticas neoliberais que privilegiam a financeirização do desenvolvimento capitalista e submetem a todos os países a aceitação dos processos de transformação institucional conducentes à corrida competitiva pelo aumento da riqueza financeira e do capital fictício em detrimento da formação de riqueza real. 
cida como "cidadã". ${ }^{10}$ Entretanto, apesar de essa Constituição conter avanços sociais formais ${ }^{11}$ inéditos na vida política nacional, já nasceu contestada pelas forças conservadoras que atuaram majoritariamente na Assembleia Nacional Constituinte (ANC) de 1987, então convocada para produzir o novo texto constitucional após 21 anos de ditadura militar. Além disso, vários dispositivos de feição social-democrata, que conseguiram ser aprovados na ANC — como a ampliação de direitos sociais, a universalização da cobertura destes e o compromisso do Estado com a garantia dos mesmos - surgiram no momento em que o neoliberalismo penetrava no país e os negava por princípio. Não por acaso, desencadeou-se, conforme Fagnani (2005), um agressivo processo de "desfiguração" das conquistas sociais previstas na Carta Magna, começando pelas leis complementares e ordinárias, que deveriam regulamentá-las, e terminando por se explicitar, não como um simples enfraquecimento dessas conquistas, mas como sucumbência destas ante os ditames do neoliberalismo. No caso da seguridade social, essa sucumbência pode ser constatada no funcionamento cada vez mais precário das políticas de saúde, previdência e assistência que compõem esse sistema, como será visto mais adiante.

São esses fatos socialmente regressivos, ao lado de conquistas simbólicas ou economicamente promissoras, que conferem ao Brasil o título de país não propriamente pobre, mas injusto, ou campeão de desigualdade social, dada a secular defasagem entre seus feitos econômicos (hoje ele é a sexta economia mundial) e seus fracos resultados sociais comparáveis.

10. Expressão usada pelo então deputado federal Ulysses Guimarães, do Partido do Movimento Democrático Brasileiro (PMDB), que presidiu a Assembleia Nacional Constituinte convocada pela Emenda Constitucional n. 26, de 1985, no governo Sarney.

11. Dentre esses avanços destacam-se: criação do conceito de seguridade social, incluindo três políticas: previdência, saúde e assistência; fixação de 50\% para o valor mínimo de remuneração das horas extraordinárias de trabalho; jornada de trabalho de 44 horas semanais; férias com mais $1 / 3$ de salário; aviso prévio proporcional; equiparação de direitos entre trabalhadores urbanos, rurais e domésticos; licença-paternidade; ampliação do tempo da licença-maternidade; $13^{\circ}$ salário para aposentados; vinculação da aposentadoria ao salário mínimo; direito à informação; instituição de um benefício de prestação continuada, no valor de um salário mínimo para idosos e pessoas com deficiência de baixa renda; criação do sistema unificado e descentralizado de saúde; valorização da democracia participativa e dos mecanismos de participação direta da população na definição de políticas e no controle das ações governamentais nas três esferas da Federação; transformação dos municípios em entes federados autônomos; conversão do Ministério Público em parte legítima na defesa dos direitos individuais e sociais indisponíveis (Pereira-Pereira, 1996). 
Efetivamente, em matéria de política social a nação brasileira continua apresentando, segundo Fagnani (2005), a seguinte configuração: de uma sociedade que nunca conseguiu vencer, como fizeram várias nações capitalistas do Ocidente, a polarização entre ricos e pobres; as deficiências estruturais e acumuladas nas áreas da saúde, educação, assistência social, seguro-desemprego, qualificação dos trabalhadores desempregados e sub-empregados; e problemas crônicos nas áreas da infraestrutura urbana (habitação, saneamento básico, transporte), da reforma agrária e das políticas de emprego e renda. E na base desses déficits sociais residem duas principais determinações: a condição capitalista periférica do Brasil e, portanto, de seu desenvolvimento retardatário, dependente e desigual/combinado, além da sua cultura colonialista; e as ditaduras que golpearam o país, as quais, a despeito de seu empenho megalomaníaco de elevar o país à condição de grande potência mundial (como aconteceu, particularmente, no governo Geisel) ${ }_{1}^{12}$ castigaram severamente as camadas mais desprotegidas da sociedade, dado ao aumento da concentração de riqueza verificado.

A conjunção desses fatores exerceu, sem dúvida alguma, infausta influência sobre as definições e rumos da política social, a partir da última redemocratização do país, porque, como já salientado, essa redemocratização ocorreu em um momento histórico adverso: processou-se na mesma época em que, nos países europeus, berço das políticas sociais regidas pela cidadania, já se aplicavam medidas contra os direitos sociais e se decidia pela implantação de um Estado mínimo (Marques, 2010, p. 1) em substituição ao Estado Social. E, nos Estados Unidos, país que se transformaria, em fins dos anos 1980, na única potência imperial, devido à autodissolução da União Soviética e ao colapso do socialismo real, o neoliberalismo radicalizaria a sua rejeição à proteção social pública e se projetaria mundialmente como uma ortodoxia sem alternativas, ${ }^{13}$

12. O governo do general Ernesto Geisel (1974-79) foi considerado o mais afeito, desde o Plano de Metas de Juscelino Kubitschek (JK), a imprimir modificações na economia brasileira, com vista a transformar o país em potência emergente. Além disso, ao contrário de JK, Geisel criou um conjunto expressivo de programas sociais "como estratégia por meio da qual se exercitaria a distensão prometida, do regime ditatorial, sem que fosse preciso destruir os seus principais instrumentos de exceção" (cf. Pereira-Pereira, 1987, p. 2229).

13. Esta é uma crença que, na Grã-Bretanha, foi sacramentada no governo da ex-primeira ministra Margareth Thatcher e veiculada, como uma espécie de mantra, pelo slogan "There is no alternative". Sintetizado na sigla Tina, tal slogan queria dizer que, depois do colapso do socialismo real, não haveria alternativa 
empunhando as seguintes consignas: do livre mercado; das privatizações do patrimônio público; da flexibilização laboral; da negação dos direitos sociais; da substituição das políticas universais pelas focalizadas; da transformação da seguridade social em simples seguro, com descarte da assistência; e da primazia do mérito empreendedor dos indivíduos em detrimento dos direitos.

Desde então, o foco principal da política social migrou ostensivamente das necessidades humanas para as necessidades do capital (Gough, 2003), isto é: voltou-se prioritariamente para satisfazer as necessidades de lucro do capital, como condição universal e necessária para a completa sobrevivência do capitalismo, que agora, na sua versão financeira/especulativa/rentista, sujeita a constantes endividamentos e bancarrotas, se tornou o alvo preferencial da assistência do Estado. E, fazendo jus à tradição, mais uma vez foi possível observar que o recente período de redemocratização no Brasil também se mostrou refratário ao desenvolvimento da política social na perspectiva da cidadania.

Esse descompasso histórico e civilizatório entre a política social brasileira e a dos países capitalistas centrais, que conheceram os chamados anos gloriosos da proteção social pública, abalou sensivelmente a utopia nacional de instituir, pela primeira vez, um regime de bem-estar, mediante o qual políticas universais na área da saúde e educação pudessem ser realizadas, a pobreza extrema (pelo menos esta) fosse, de fato, minimizada, e o trabalho se tornasse valorizado e protegido, além de a população poder participar diretamente do controle das políticas públicas, por meio de mecanismos de democracia participativa, também previstos na Constituição Cidadã.

Diante dessa realidade, cabem as seguintes perguntas para se avançar na reflexão: a quem os Estados nacionais capitalistas, movidos pela sedução do desenvolvimento (incluindo o Brasil), mais assistem hoje: aos ricos ou aos pobres? Porque a assistência aos ricos não causa a perplexidade e a celeuma que a irrisória assistência aos pobres provoca nos círculos midiáticos, intelectuais

\footnotetext{
ao liberalismo econômico e aos livres mercado e comércio, assim como à globalização neoliberal; e que este seria o caminho a ser trilhado pelas sociedades modernas em direção ao progresso.
} 
e políticos? E por que o combate à concentração de riquezas não é alvo preferencial dos governos, mas sim, a redução ou o alívio da pobreza?

As respostas a essas perguntas podem ser sintetizadas no seguinte argumento defensor do neoliberalismo: de que a falência dos especuladores financeiros levaria ao caos econômico geral; e que a regulamentação da economia e dos mercados movidos pelo capital especulativo, fictício, "portador de juros" (Chesnais, 2010), significaria opção por uma ordem não liberal, tendente ao socialismo e, portanto, impensável.

Porém, para além desse argumento, há algo mais que precisa ser conhecido em relação à recusa neoliberal de assistir, de fato, aos pobres. É que, sob o domínio do neoliberalismo, construíram-se ortodoxias ideológicas e moralistas (Dean, 2006), em torno de uma ética de autorresponsabilização dos indivíduos pobres, que obriga a estes a autossatisfazerem suas necessidades sociais; ou, então, a darem algo em troca pelos auxílios públicos recebidos, como se fossem eternos devedores, e não credores, de vultosas dívidas sociais (Pisón, 1998).

Donde se conclui que a ética da autoproteção social que está se fortalecendo e se impondo como a ortodoxia do momento mundo afora, incluindo o Brasil, funciona apenas para os pobres e, por isso, produz as seguintes consequências: focaliza a política social na pobreza extrema e transforma essa política em instrumento de ativação dos indigentes para o trabalho, geralmente precário, por meio de condicionalidades ou contrapartidas que, na maioria das vezes, revelam-se autoritárias e punitivas. Em verdade, o predomínio contemporâneo da ética da autorresponsabilização no contexto mundial da política social mostra que está havendo um contínuo e crescente esvaziamento do padrão capitalista de Estado social de direito em favor do padrão capitalista de Estado neoliberal meritocrático, laborista, ou do que a literatura especializada vem chamando de transição do Welfare State para o Workfare State. É o que, com outras palavras, LöicWacquant (2007) vem falando da substituição do Estado Social pelo Estado Penal, principalmente quando se refere aos Estados Unidos, por sinal o país precursor da ideologia do work fare (bem-estar em troca de trabalho, não importa qual) em substituição ao welfare (bem-estar incondicional, como direito). 


\section{Implicações para as políticas sociais das utopias desenvolvimentistas sob a égide do credo neoliberal: o caso particular da Seguridade Social brasileira}

Do exposto, é possível entender "o longo calvário", como diz Fagnani (2007), da trajetória da Seguridade Social brasileira que, com ineditismo, "transcendeu o modelo regressivo de seguro social vigente no pós-64" (p. 40) e, com esse perfil, integrou o texto da Constituição Federal de 1988. E mais: é possível entender as razões que impediram os governos pós-ditadura militar de instituir no Brasil um Estado social de direito, tal como já experimentado por outros países capitalistas. Afinal, com a Constituição de 1988 não se estava propondo nada radical, que sugerisse a passagem do capitalismo para o socialismo, mas tão somente a entrada retardatária do Brasil num processo civilizatório próprio das chamadas democracias burguesas.

Entretanto, nem assim as forças conservadoras que se mantiveram ativas, inclusive em postos-chave da denominada "Nova República", ${ }_{14}^{14}$ que se seguiu à ditadura, absorveram os avanços constitucionais. E, desde então, deu-se início ao que vários autores, incluindo Fagnani, chamam de "contrarreforma" 15 conservadora às reformas institucionais realizadas, mas que, a meu ver, representou mais do que isto: houve, de fato, destruição das frágeis conquistas democráticas consignadas na Constituição, praticada pelo Estado ou com o seu aval. É o que demonstram os seguintes fatos: a própria ideia de Seguridade Social, contida

14. Nome dado ao período da história do Brasil que se seguiu ao fim da ditadura militar implantada em 1964.

15. Segundo Coutinho (2010, p. 32-38), o termo "contrarreforma" foi usado por Gramsci, embora de forma marginal. Se compararmos o referido termo com o conceito gramsciano de "revolução passiva" — que inclui o momento da "restauração" (reação conservadora a transformações radicais provenientes "de baixo", mas sem deixar de combinar o velho e o novo) e o momento de "renovação" (no qual demandas populares são estrategicamente atendidas pelas camadas dominantes) - por contrarreforma se entenderá não a restauração e nem a renovação, mas a preservação do velho, como aconteceu com o movimento da Igreja Católica, no Concílio de Trento, contra a Reforma Protestante. Ademais, os ideólogos do neoliberalismo, ainda segundo Coutinho, gostam de se apresentar como amigos do progresso e usam a palavra "reforma" para expressar a sua adesão às exigências da modernidade ou da chamada pós-modernidade. Não admira, portanto, a autointitulação de seu movimento como "revolução liberal" contra o estatismo, ou seja, como destruição ao que considera velho, mediante cortes, restrições e supressões. Todavia, Coutinho admite que, no Brasil, no rastro dos programas sociais compensatórios dos últimos anos pode ser identificada uma tendência de "contrarreforma”, já que, com os mesmos, procura-se preservar uma enorme carga de conservadorismo. Só que, contrarresto eu, trata-se de um conservadorismo a serviço da destruição implacável dos direitos sociais. 
pela primeira vez numa Carta Magna, não vingou no país. A Seguridade pensada como um conjunto de ações integradas, destinadas a assegurar direitos sociais universais nos campos da previdência, saúde e assistência social (independentemente de contribuição individual para essas duas últimas políticas), conforme art. 194 da CF/88, não se estruturou, seja como conjunto orgânico, seja como política concretizadora de direitos universais.

Além disso, o orçamento que foi concebido para financiar as políticas de Seguridade Social (OSS), tendo como principal bandeira a utilização de fontes que incidissem sobre o faturamento e o lucro das empresas, teve essa bandeira rejeitada. Com isso, caíram por terra duas importantes estratégias progressistas embutidas na proposta de criação de um orçamento específico para a Seguridade: controlar democraticamente os recursos que deveriam financiar as suas políticas e evitar que esses recursos fossem capturados pela área econômica $\mathrm{e}$ desviados de seu verdadeiro destino, como de fato aconteceu.

Por conseguinte, nenhuma das três políticas que compõem o conjunto da Seguridade Social brasileira foi implementada, como previsto na Lei Maior. Para isso, contribuíram prognósticos conservadores de que elas levariam o país à ingovernabilidade (governo Sarney) ou incitariam a preguiça (deputado constituinte Delfim Neto), emitidos durante os trabalhos da Assembleia Nacional Constituinte.

Assim, se atualmente existem dados estatísticos que indicam ter havido no Brasil "neodesenvolvimentista" diminuição da pobreza com crescimento sustentado, é preciso comparar esses dados com a seguinte realidade: nenhum governo brasileiro pós-ditadura militar, e eleito diretamente pelo povo, rompeu com os mandamentos neoliberais, nem mesmo os que se identificavam com projetos de esquerda.

O curto governo Collor de Mello (1990-92) e os dois mandatos de Fernando Henrique Cardoso — FHC (1995-98/1999-2002) foram mais explícitos na sua rejeição aos preceitos constitucionais favoráveis à ampliação dos direitos sociais no país. Mas o governo de Luiz Inácio Lula da Silva, sobre quem recaíram as esperanças das esquerdas de se contrapor às políticas neoliberais de seus antecessores, também não se mostrou, nos seus dois mandatos (2003-06/2007-10), fiel seguidor desses preceitos. Ao contrário, conforme Oliveira (2010), e contra todas as expectativas, Lula seguiu a senda neoliberal 
aberta por Collor e alargada por FHC, para acabar por aumentar a autonomia do capital. Assim, ao fim e ao cabo, "se FHC destruiu os músculos do Estado para implementar o projeto privatista, Lula [destruiu] os músculos da sociedade, que já não se opõe às medidas de desregulamentação" (p. 375) adotadas desde antes do seu governo.

Entrando em detalhes, Collor de Mello demonstrou claramente que pretendia destruir os avanços sociais contidos na Carta Magna, por ocasião da revisão desta, prevista para 1993, no art. $3^{\circ}$ das suas Disposições Transitórias, e só não concretizou esse intento por ter sido afastado, por meio de um impeachment, da presidência da República antes do término de seu mandato. Graças a isso, como diz Fagnani (Idem, 2007), “o funeral da Carta de 1988 teve de ser adiado" (p. 51).

Mesmo assim, Collor de Mello cometeu vários atentados contra o capítulo da Seguridade Social da Lei Maior, entre os quais se destacam: reiterou o tradicional tratamento fragmentado das três políticas que compõem o sistema, identificando, à revelia da Constituição, a seguridade com um simples seguro; ${ }^{16}$ desfigurou o orçamento da Seguridade Social ao utilizar recursos desse orçamento para outros fins e — no que concerne à Previdência Social — para transformar em adicionais as contribuições da União que antes integravam regularmente esse orçamento; desvinculou os benefícios previdenciários do salário mínimo; postergou por um ano a regulamentação do Plano de Custeio da Previdência Social; ${ }^{17}$ represou, até o final de seu governo a concessão dos benefícios previdenciários, apesar de estes já estarem regulamentados; vetou 25 itens da Lei Orgânica da Saúde, que também já tinham sido aprovados pelo Congresso Nacional, a maior parte dos quais referentes ao financiamento do Sistema Único de Saúde (SUS) e à participação dos segmentos sociais no ge-

16. Isso explica o fato de o Projeto de Lei da Assistência Social, aprovado no Congresso Nacional, ter sido integralmente vetado pelo executivo, e considerado pelo então presidente da República um documento que continha "dispositivos contrários aos princípios de uma assistência social responsável, que se limite a auxílios às camadas mais carentes da população" (Collor, 1990).

17. Em novembro de 1990, o Poder Executivo vetou integralmente o Projeto de Lei n. 47/90, aprovado em agosto de 1990 pelo Congresso Nacional, que regulamentava o referido Plano. Mas em dezembro de 1990 o veto presidencial foi derrubado pelo Congresso e somente em julho de 1991 o Projeto foi regulamentado, respectivamente, pelas Leis n. 8.212/91 e n. 8.213/91 (Fagnani, 2007). 
renciamento desse sistema; e não admitiu que a assistência social fosse transformada em política de Seguridade Social, vetando integralmente o seu projeto de lei, aprovado no Congresso Nacional. No que se refere ao seguro-desemprego, capitulado no art. $7^{\circ}$, inciso II, da $\mathrm{CF} / 88$, como direito do trabalhador, vale destacar outros desvios dos preceitos constitucionais, tais como: a utilização dos recursos do Fundo de Assistência do Trabalhador (FAT) em aplicações do Banco do Brasil e para financiar o Instituto Nacional de Assistência Médica da Previdência Social-Inamps (Fagnani, 2007).

Essas foram, entre outras, as primeiras investidas inconstitucionais de gestão neoliberal das políticas sociais no Brasil, as quais tiveram como facilitadores dois fatos históricos interligados: um internacional e outro nacional. $\mathrm{O}$ primeiro, já mencionado, foi o fim da bipolaridade mundial, em 1989, resultante da autodissolução da União Soviética e da ascensão dos Estados Unidos à única potência imperial. E o segundo foi o esgotamento, no Brasil, do Estado desenvolvimentista clássico e a consequente reorganização das classes dominantes em torno do projeto neoliberal, que perseguia o progresso via protagonismo do mercado. Isso explica por que, após a retirada de Collor da Presidência e de um período (entre outubro de 1992 e meados de 1993) de "instabilidade política e de indefinição da estratégia econômica do governo" (Fagnani, 2007, p. 53), a ofensiva neoliberal ganhou vigor nos dois mandatos de Fernando Henrique Cardoso. Efetivamente, nesse governo, o país foi aberto às ingerências neoliberais e regido pelas teses do Consenso de Washington. ${ }^{18}$

Foi com FHC, portanto, que ocorreu a maior incompatibilidade entre a agenda governamental e os direitos sociais previstos na Constituição de 1988.

18. Consenso de Washington foi a designação adotada, em 1989, pelo economista inglês John Williamson, para um conjunto de receitas econômicas estabelecidas durante a preparação de uma conferência organizada pelo Institute for International Economics (IIE), de Washington. Em linhas gerais, faziam parte desse receituário as privatizações, a abertura da economia e o controle da inflação e do déficit público, que podem ser sinteticamente desdobradas nas seguintes teses: limitação dos gastos do Estado à arrecadação, com o fito de eliminar o déficit público; redução dos gastos públicos e sua focalização; reforma tributária com vista a ampliar o peso dos impostos indiretos e diminuir a progressividade nos impostos diretos; liberalização/desregulamentação financeira e retirada do Estado do setor; taxa competitiva de câmbio; liberalização do comércio exterior para impulsionar a globalização da economia; eliminação de restrições ao capital externo; privatização com venda de empresas estatais; desregulamentação do processo econômico e das relações trabalhistas; defesa da propriedade intelectual (Matoso, 2010, p. 34). 
Ao privilegiar, políticas monetárias, cambiais e fiscais implícitas no seu Plano Real, ${ }^{19}$ em detrimento de uma política econômica socialmente referenciada, cedo o Brasil voltou a ostentar elevados índices de desemprego formal, de achatamento dos salários, de aumento da carga tributária, de privatização do patrimônio público, de desfinanciamento das políticas sociais, de repúdio à política de assistência social, cujas funções passaram a ser transferidas para o setor voluntário da sociedade, reeditando-se, assim, o velho assistencialismo. E uma prática desse governo que mais penalizou as políticas de Seguridade foi a transferência de receitas dessa área, constitucionalmente garantidas, para o setor econômico, por meio da DRU (Desvinculação dos Recursos da União) associada ao intento de reduzir a Seguridade Social mero seguro. Que o diga a Emenda Constitucional n. 20/98 (EC n. 20/98), a qual, em nome do ajuste fiscal, concebeu uma "reforma" na Previdência Social que praticamente destruiu os preceitos constitucionais sobre a aposentadoria. De acordo com essa EC, a comprovação do tempo de serviço foi substituída pelo tempo de contribuição; a aposentadoria proporcional foi eliminada; os benefícios previdenciários (situados acima do piso) foram desvinculados do salário mínimo; e o teto nominal dos benefícios foi rebaixado (Fagnani, 2007). Enfim, "manipulando o fetiche da moeda estável, Fernando Henrique retirou do Estado brasileiro a capacidade de fazer política econômica" (Oliveira, 2010, p. 373) e, vale acrescentar também social. Em decorrência disso, pode-se dizer que nesse governo prevaleceu uma política monetária aliada a uma ousada e desastrosa prática de privatização das empresas estatais, mediante a qual o setor privado da economia foi agraciado com renda, riqueza e patrimônio em detrimento do bem-estar social da população (Oliveira, Idem).

O governo Lula, que se iniciou em 2003, deparou-se com um cenário desolador do ponto de vista das expectativas das esquerdas, caracterizado, de um lado, pelo refluxo das lutas sociais e da combatividade das hostes trabalhistas e, de outro, pela desfiguração da Constituição e desmonte das bases finan-

19. Trata-se do mais amplo e eficaz plano econômico adotado no Brasil, em 27 de fevereiro de 1994, no governo FHC. Criado pela Medida Provisória n. 434, o referido plano visava controlar a hiperinflação que assolava o país, mediante uma série de medidas de cunho eminentemente monetário, que incluíam a criação de uma nova moeda prevalecente até hoje — "o real". 
ceiras do sistema de Seguridade Social. Sobre esse cenário, Sader (2011), repetindo uma frase de Perry Anderson, formulada em outro contexto, afirma que, "quando a esquerda finalmente chegou ao governo, tinha perdido a batalha das ideias" (p. 125). Com isso, Sader queria dizer que "quando Lula finalmente triunfou, já se havia imposto ao longo dos anos 1990, tanto no Brasil como na América Latina e no mundo, a hegemonia neoliberal com todas as suas implicações" (Idem). E no Brasil, especificamente, já se havia imposto uma década de governo neoliberal, centrado no controle da inflação, mas causador de uma recessão grave e duradoura e de uma enorme dívida social acumulada.

Diante desse legado, considerado "maldito", o governo Lula adotou uma postura ambígua: optou pela continuidade da herança recebida, mas sem descurar da “incorporação de parte das reivindicações dos 'de baixo' com a bem orquestrada reação ao subversivismo esporádico das massas, representado pelo 'transformismo de grupos inteiros"' (Braga, 2010, p. 13). Ou, conforme o mesmo autor (Idem), tal incorporação e tal transformismo foram viabilizados por um jogo político manejado pelo Estado, que transitou da oferta aos grupos com maior capacidade de insurgência de uma

miríade de cargos no aparato de Estado até a reformas indical que robusteceu os cofres das centrais sindicais, passando pelos muitos assentos nos conselhos gestores dos fundos de pensão, pelas altas posições em empresas estatais, pelo repasse de verbas federais para financiamento de projetos cooperativos, pela recomposição da máquina estatal etc.[...]. O fato é que o subversivismo inorgânico transformou-se em consentimento ativo para muitos militantes sociais, que passaram a investir esforços desmedidos na conservação das posições adquiridas no aparato estatal.

De par com esse processo, ao optar pelo não rompimento com os fundamentos da política neoliberal, o governo Lula, no seu primeiro mandato (2003-06), não só continuou com a política de ajuste macroeconômico do governo FHC, como a intensificou; e, ao lado do reforço à estabilização econômica, realizou uma minirreforma tributária para elevar a receita da União e uma nova reforma da Previdência para estabilizar o déficit do regime previdenciário dos servidores públicos em relação ao PIB (Nakatani e Oliveira, 2010), na qual 
os aposentados voltaram a contribuir com $11 \%$. Isso repercutiu desfavoravelmente nas políticas sociais e nas condições de vida da classe trabalhadora (e dos aposentados) porque, junto com essas medidas, a concentração de riquezas manteve-se intocada; ou melhor, a hegemonia do capital financeiro, o monopólio da terra e os fundos privados de pensão foram preservados e incentivados. E, atendendo pressões transnacionais, o governo adotou políticas de liberação dos transgênicos e de formação de superávit primário para remunerar capitais financeiros (Antunes, 2011, p.129). Com isso, o governo Lula perdeu apoios históricos junto às forças de esquerda que o apoiaram em sua corrida à presidência, após três tentativas consecutivas; mas, em compensação, ganhou um amplo leque de adesões à direita e à esquerda que the garantiu suporte político supra e policlassista. Portanto, nesse período, não se pode dizer que o governo Lula tenha realizado políticas sociais significativas, a despeito do seu empenho em acabar com a fome no país, por meio do Programa Fome Zero, cujo carro-chefe se tornou o Programa Bolsa Família, e de ter conseguido expressivo crescimento econômico.

Em seu segundo mandato, e com o crescimento econômico em recuperação, após 25 anos de letargia, Lula expandiu a cobertura do Bolsa Família abarcando mais de 12 milhões de unidades familiares de baixa renda. Destarte, de acordo com documentos oficiais (MDS, 2011), Lula retirou 28 milhões de pessoas da pobreza, levou 36 milhões à classe média e reduziu para 8,5\% (16,27 milhões) o número de brasileiros em estado de pobreza absoluta ou de miséria. As estatísticas também mostram que no período compreendido entre 2002 e 2010 o desemprego caiu de $12 \%$ para $5,7 \%$ e o rendimento das pessoas ocupadas aumentou em 35\% em termos reais. Além disso, a partir de 2004, o volume de ocupações formais começou a crescer, atingindo, em 2009, um recorde histórico - 59\% dos trabalhadores com carteira assinada - (IBGE/PNAD, 2009); e o salário mínimo teve pequena valorização em termos reais.

Visando diminuir a informalidade do trabalho - cuja expressiva existência retém potenciais contribuições à Previdência, além de privar o trabalhador de proteções sociais formais -, o governo Lula também incentivou a expansão de micro ou pequenas empresas e do trabalho autônomo regulamentado, com vista à geração alternativa de trabalho e renda. Para tanto, flexibilizou as exigências burocráticas à criação desses empreendimentos e reduziu os custos dos 
impostos para essa operação, mediante aplicação de mecanismos tributários e jurídicos especiais. Nesse sentido, instituiu o programa Simples, em 2007, e, em 2008, editou a Lei do Microempreendedor Individual (MEI), voltada para o trabalhador autônomo com, no máximo, um funcionário e faturamento anual de 36 mil reais; e, em 2009, instituiu o Prime, um programa de financiamento de pequenos empreendimentos administrado pela Financiadora de Estudos e Projetos (Finep), ligada ao Ministério da Ciência e Tecnologia. Tais medidas, que iam, como já assinalado, da redução de impostos e do tempo gasto com providências administrativas à concessão de créditos especiais, passando pelo microcrédito produtivo orientado, pela economia solidária no conjunto do aparelho produtivo e pela facilidade nas licitações, contribuíram para uma notável ascensão desse setor, a saber: em 2008 havia 31 milhões de ocupados em empreendimentos com até dez trabalhadores, o que, comparado com os 14,1 milhões em 1989, representa mais de 100\% (Ipea, 2008).

Contudo, em que pesem esses avanços, vale conferir a seguinte e paradoxal constatação, que põe em xeque a pretensão neodesenvolvimentista do governo Lula: esse governo melhorou, sim, as condições sociais de muitos brasileiros, mas, ao mesmo tempo, melhorou muito mais a remuneração do capital financeiro, industrial e do agronegócio que operam no país. Ou seja, foi no governo Lula que o enfrentamento da pobreza absoluta teve a maior visibilidade política de sua endêmica existência, mas, paradoxalmente, isso foi acompanhado da garantia "de altos lucros, comparáveis com os mais altos da história recente do Brasil" (Antunes, 2011, p. 131) a diversas frações do capital. Portanto, se a pobreza absoluta ou extrema diminuiu a desigualdade, não sofreu decréscimos; ${ }^{20}$ e se a pobreza absoluta ou extrema preocupou o governo, o combate à concentração de riqueza não foi alvo dessa preocupação. E o país continua injusto.

20. A esse respeito, Oliveira (2010, p. 373) sustenta que "os dados disponíveis não indicam redução da desigualdade, embora deva ser certo que a pobreza absoluta diminuiu. Mas não se sabe quanto. A desigualdade provavelmente aumentou, e os resultados proclamados são falsos, pois medem apenas as rendas do trabalho, que, na verdade melhoraram muito marginalmente, graças aos benefícios do INSS, e não do Bolsa Família [...]. É impossível medir desigualdade total de rendas: em primeiro lugar, pela conhecida subestimação que é prática no Brasil e, em segundo lugar, por um problema de natureza metodológica (conhecida de todos que lidam com estratificações), que é a quase impossibilidade de fechar o decil superior da estrutura de rendas". 
Ademais, cabe registrar a adesão desse governo à ética capitalista neoliberal do workfare, que se expressa, seja na cobrança de contrapartidas dos beneficiários da assistência social pública, para livrá-los da dependência desta, seja na ativação imperiosa desses beneficiários para a sua inserção no mercado de trabalho com vista a sua autossustentação.

Foi certamente com base nessa ética que o governo Lula firmou convênio com a Câmara Brasileira de Indústria de Construção para que fossem reservadas vagas nas obras de construção civil do PAC para os beneficiários do Programa Bolsa Família. Contudo, mesmo esse mercado de trabalho, aparentemente capaz de absorver mão de obra pouco qualificada, tem reclamado da falta de condições básicas (que não se prendem ao aspecto profissional) desses beneficiários para o desempenho das tarefas requeridas - o que tem solicitado da educação uma interferência também precária, sob a forma de treinamentos pontuais. E em meio a essas providências, cujo maior apelo workfarista é o de criar as chamadas portas de saída da "tutela assistencial" do Estado (considerada uma heresia pelo credo neoliberal), esqueceu-se que o atual mercado de trabalho é incapaz de absorver um contingente de desempregados que ele mesmo cria, humilha e despreza.

Sobre o governo Dilma, cumpre assinalar que o seu "Plano Brasil sem Miséria", já dá mostras de que a ultrafocalização, ou o princípio da minimalissima elegibilidade, associados à prevalência do workfare sobre o welfare, serão as tendências privilegiadas. Isso porque a presidente Dilma rebaixou, formalmente, os critérios preexistentes para a definição da pobreza e da miséria no Brasil, conseguindo, desse modo, diminuir estatisticamente um bom número de pobres e miseráveis. Para tanto, adotou como critério definidor de pobreza e indigência o utilizado pela Organização das Nações Unidas (ONU) na definição de suas metas do milênio, o qual, por ser o mais restrito entre outros disponíveis, considera pobre a família com renda mensal de até 120,00 reais e indigente a que ganha mensalmente até 70,00 reais (1,25 dólares/dia). E como os indigentes serão o alvo prioritário do atual governo, este espera erradicar a miséria artificialmente restringida, no país (cerca de 16 milhões de pessoas), usando a assistência para ativar os beneficiários dos programas dessa área, e seus familiares adultos, para o trabalho ou a geração de renda precários. 


\section{Conclusão}

Constata-se que a conjuntura mundial e brasileira da política social é sombria, não obstante, no Brasil, grassar o discurso de um novo desenvolvimentismo no rastro da elevação do país à condição de economia emergente. Mais do que nunca prevalecem tendências que já vêm se impondo à algum tempo, a saber:

a) A direitização da política social, já que esta foi, desde os anos 1980, capturada pelo ideário neoliberal, que não tem compromissos sociais, e submetida aos seus desígnios. Por isso, não é exagerado afirmar que em todo mundo, inclusive no Brasil, vive-se sob o império de políticas sociais de (ultra) direita.

b) A monetarização da política social, uma vez que esta não mais visa concretizar direitos sociais, mas fortalecer o mérito individual do pobre de conseguir, por meio do mercado, a satisfação de suas necessidades. As privilegiadas opções governamentais de repassar dinheiro aos pobres em lugar de garantir-lhes, como dever de cidadania, serviços sociais públicos, empregos e salários de qualidade, não são ingênuas e nem assistenciais. Tais opções apostam no poder mágico, fetichista, do dinheiro, que transforma os pobres em consumidores; e, no Brasil, também os transforma em uma significativa massa de pagadores de impostos, já que o sistema tributário brasileiro é altamente regressivo e grandemente incidente no consumo. Ademais, um efeito secundário da monetarização da política social é a transformação desse tipo de consumidor em portador de cartão de crédito ou comprador de produtos a prazo e, por conta disso, permanentemente endividado. Assim, embora muitas dessas pessoas sintam que melhoraram de vida e demonstrem otimismo em relação ao futuro, esse sentimento se apoia num nível crescente de endividamento, geralmente impagável. Entretanto, esse esquema funciona como uma bomba relógio porque, se por um lado o mercado lança na praça facilidades de compra, produtos antes escassos e fatura com as altas taxas de juros ao consumidor, por outro há o risco de inadimplência generalizada, gerador de futuras consequências que, em relação aos pobres, não terão nada de assistenciais. 
c) A laborização precária da política social, visto que a principal responsabilidade desta, principalmente da assistência, é a de ativar os demandantes da proteção social para o trabalho. Mas como esse é escasso e não há possibilidades de inserir todos no mercado formal, os governos têm apelado para ações empreendedoristas, de baixo custo e nível, para que até mesmo a singela responsabilidade pública de transferir renda básica aos pobres, de forma compensatória, seja substituída pelo labor impositivo dos mesmos.

d) Adescidadanização da política social, porque a maior parte do trabalho oferecido pela ética da autorresponsabilização dos pobres pelo seu próprio sustento e bem-estar é dissociada da cidadania; ou melhor, trata-se de trabalho precário (apesar de primar pela intensificação qualitativa dos ritmos produtivos, haja vista o caso dos operadores de telemarketing), flexível, mal pago e desprotegido. E o que vem sendo chamado de assistência tem mais caráter de penitência, tal como acontecia no século XIX sob a regência do sistema das workhouses inglesas, alcunhadas pejorativamente de novas bastilhas. Parece até que, em matéria de política social, o século XXI foi empurrado para o século XIX.

e) Por fim, uma recorrente e flagrante tendência que sustentou a utopia desenvolvimentista brasileira em seus diferentes períodos, inclusive no dos governos pós-ditadura militar, foi a que se operou (e continua operando) à margem da participação social. Para Paulani (2010), nesse processo, sempre houve uma relação estreita entre poder e dinheiro e, como tal, uma marcante discricionariedade dos governos, que abusaram da decretação de uma espécie de "estado de emergência econômica" para poderem agir em regime de exceção diante de problemas que, segundo eles, levariam o país ao precipício. Isso foi assim nas ditaduras e continuou sendo do mesmo jeito nos períodos das antigas e da recente redemocratização, a começar, nessa última, com o Plano Cruzado, ${ }^{21}$ de 1986, do governo Sarney. No governo Lula tal expediente

21. Conjunto de medidas criado no governo Sarney (1985-90), em 28 de fevereiro de 1986, com o objetivo básico de conter a inflação. Dentre as medidas adotadas — como a suspensão da correção monetária, o congelamento dos preços, a implantação da escala móvel dos salários - , ressalta a troca da moeda, 
combinou o uso do estado de emergência econômica com o que a autora, baseada em Francisco de Oliveira, chama de "hegemonia às avessas", isto é: o exercício da liderança material (exploração) pela classe burguesa, sob o beneplácito das classes dominadas que acreditaram exercer a liderança moral e intelectual, invertendo, assim, o conceito de hegemonia gramsciana. Portanto, no contexto das tendências contemporâneas da política social brasileira, pode-se acrescentar essa peculiaridade do desenvolvimento econômico nacional, porque no fundo ela responde, em grande parte, pela dissociação dessa política dos direitos de cidadania social. Afinal, direitos não combinam com estados de exceção.

Em suma, sob o discurso da mudança radical da governança do Estado, a preocupação dominante é a de encontrar soluções rápidas e menos onerosas para liberar os pobres da proteção social pública. A grande novidade tem sido a ativação compulsória dos demandantes dessa proteção para o trabalho, mediante a combinação de objetividade programática com simplicidade administrativa e baixo nivel de investimento educacional. A educação, nesse contexto, reduz-se a treinamento ou adestramento aligeirado para um mercado de trabalho instável e flexível, enquanto a assistência social deixa de fazer parte de uma rede de proteção para se transformar em trampolim para esse tipo de trabalho. E em vários países, caso o assistido se negue a ser treinado para assumi-lo, ele será tratado como uma espécie de pária social. (Pereira-Pereira, 2009, p. 288).

Essas são as tendências de fato dominantes que contradizem o conceito de desenvolvimento no Brasil. Mas, é bom lembrar que elas não são fatais. Pelo fato de a política social ser um processo complexo e internamente contraditório

\footnotetext{
cujo nome deixou de ser cruzeiro para ser cruzado, na qual o valor da unidade monetária (1,00 cruzado) passou a correspondera mil unidades do cruzeiro. Sarney foi de fato o primeiro presidente civil após os 21 anos da ditadura militar. Mas foi indicado indiretamente por um Colégio Eleitoral, como vice de Tancredo Neves, que faleceu antes de tomar posse do cargo de presidente, também indicado, de forma indireta, pelo mesmo Colégio. Em vista desse fato, em 14 de março de 1985 Sarney assumiu a presidência interinamente, devido à internação hospitalar de Tancredo; e, em 21 de abril do mesmo ano, tornou-se presidente definitivo, devido à morte do titular.
} 
- e não um sistema, um ato formal de Estado ou de governo, uma receita técnica ou mera resposta institucional -, ela pode mudar de tendência e ser colocada a serviço do trabalho na sua luta endêmica contra o capital. Tudo vai depender do impacto das mudanças estruturais em curso sobre os rumos da história, do regime político vigente, da organização e movimento da sociedade, da correlação de forças em presença e do sentido de desenvolvimento que se deseja imprimir.

Recebido: 1/8/2012 - Aprovado em 13/8/2012

\section{Referências bibliográficas}

ANTUNES, Ricardo. O Brasil da era Lula. Margem Esquerda, Ensaios Marxistas. São Paulo, n. 16, 2011.

BRAGA, Ruy. Apresentação. In: OLIVEIRA, Francisco; BRAGA, Ruy; RIZEK, Cibele. Hegemonia às avessas. São Paulo: Boitempo, 2010.

CHESNAIS, François. Prefácio. In: MARQUES, R. M.; FERREIRA, M. R. J. O Brasil sob a nova ordem. São Paulo: Saraiva, 2010.

COLLOR, Fernando. Mensagem n. 672. Diário Oficial, Brasília, Seção I, terça-feira, 18 set. 1990.

COUTINHO, Carlos Nelson. Hegemonia da pequena política. In: OLIVEIRA, Francisco; BRAGA, Ruy; RIZEK, Cibele. Hegemonia às avessas. São Paulo: Boitempo, 2010 .

DEAN, Hartley. Activation policies and the changing ethical foundations of welfare. In: ASPEN/ETUI Conference: activation policies in the EU, Bruxelas, 20-21 out. 2006.

FAGNANI, Eduardo. Política social no Brasil (1964-2002): entre a cidadania e a caridade. Tese (Doutorado em Ciências Econômicas) - Instituto de Economia da Unicamp, Campinas, 2005.

. Seguridade Social no Brasil (1996/2006): longo calvário e novos desafios. In:

CESIT. Carta Social e do Trabalho, Campinas, n. 7, set./dez. 2007. 
FURTADO, Celso. O mito do desenvolvimento econômico. 2. ed. Rio de Janeiro: Paz e Terra, 1974.

GOUGH, Ian. Capital global, necesidades básicas y políticas sociales. Madrid/Buenos Aires: Miño y Dávila editores/Miño y Dávilasrl, 2003.

IBGE. Pesquisa Nacional por Amostra de Domicílios (PNAD). v. 30, 2009.

IPEA. Políticas Sociais: Acompanhamento e Análise. Brasília, n. 16, nov. 2008.

MARQUES, Rosa M. O regime de acumulação sob a dominância financeira e a nova ordem no Brasil, In: ; FERREIRA, M. R. J. O Brasil sob a nova ordem. São Paulo: Saraiva, 2010.

MATOSO, Jorge. O Brasil herdado. In: SADER, E; GARCIA, M. C. Brasil entre o passado e o futuro. São Paulo: Boitempo, 2010.

MINISTÉRIO DE DESENVOLVIMENTO SOCIAL E COMBATE À FOME (MDS). Nota MDS. O perfil da extrema pobreza no Brasil com base nos dados preliminares do universo do Censo 2010. Brasília, 2 maio 2011.

MISHRA, Ramesh. The Welfare State in capitalist society: policies of retranchement and maintenance in Europe, North America and Australia. Londres, Harvester/Wheatshef, 1990.

MORENO, Luis. Ciudadanos precários: la "última red” de protección social. Barcelona: Editorial Ariel, S. A., 2000.

NAKATANI, Paulo; OLIVEIRA, Fabrício A. Política econômica brasileira de Collor a Lula: 1990-2007. In: MARQUES, R. M; FERREIRA, M. R. J. O Brasil sob a nova ordem. São Paulo: Saraiva, 2010.

OLIVEIRA, Francisco. O avesso do avesso. In: ; BRAGA, Ruy; RIZEK, Cibele. Hegemonia às avessas. São Paulo: Boitempo, 2010.

PAULANI, Leda Maria. Capitalismo financeiro, estado de emergência econômico e hegemonia às avessas no Brasil. In: OLIVEIRA, Francisco; BRAGA, Ruy; RIZEK, Cibele. Hegemonia às avessas. São Paulo: Boitempo, 2010.

PEREIRA-PEREIRA, Potyara A. Crítica marxista da teoria e da prática da política social no capitalismo: peculiaridades da experiência brasileira. Tese (Doutorado) Universidade de Brasília/ Departamento de Sociologia, Brasília, 1987.

. Assistência social na perspectiva dos direitos: crítica aos padrões dominantes de proteção ao pobre no país. Brasília: Thesaurus, 1996. 
PEREIRA-PEREIRA, Potyara A. Do Estado social ao Estado antisocial. In: PEREIRA-PERERA, Potyara A. et al. (Orgs.). Política social, trabalho e democracia em questão. Brasília: Universidade de Brasília, Programa de Pós-Graduação em Política Social, Departamento de Serviço Social, 2009.

PISÓN, Jose M. José Martinez de. Políticas de bienestar: un estudio sobre los derechos sociales. Madri: Tecnos, 1998.

REPÚBLICA FEDERATIVA DO BRASIL. Constituição de 1988. Brasília: Câmara dos Deputados, Coordenação de Publicações, 2002.

SADER, Emir. Desequilíbrios estruturais do capitalismo atual. Le Monde Diplomatique, Brasil, set. 2008.

. Brasil, de Getúlio a Lula. In: ; GARCIA, M. C. Brasil entre o passado e o futuro. São Paulo: Boitempo, 2010.

. Neoliberalismo versus pós-neoliberalismo: a disputa estratégica contemporânea. In: Margem esquerda, ensaios marxistas. São Paulo: Boitempo, 2011.

WACQUANT, Löic. Punir os pobres: a nova gestão da miséria nos Estados Unidos. 3. ed. rev. e ampl. Rio de Janeiro: Revan, 2007. 